\title{
EKSPLORASI DAN PENERAPAN RAGAM HIAS BATIK JAWA TIMUR PADA KERAJINAN SULAM TANGAN
}

\author{
Pramita Larasati ${ }^{1}$ \\ Dudy Wiyancoko ${ }^{1}$ \\ Gita Winata $^{1}$ \\ Institut Teknologi Bandung, Bandung ${ }^{1}$ \\ pramitalarasati13@gmail.com
}

\begin{abstract}
Abstrak
Sulam merupakan salah satu kerajinan yang telah ada di Indonesia sejak dulu kala. Biasanya kerajinan sulam diaplikasikan pada berbagai barang keperluan adat seperti pelaminan pernikahan, penutup hantaran hingga digunakan sebagai penghias busana yang dikenakan. Kerajinan sulam di Indonesia banyak berkembang di pulau Sumatera dan Kalimantan. Namun, karna tingkat kesulitan dan lamanya waktu pembuatan kerajinan sulam khas Indonesia memiliki harga jual yang cukup tinggi. Hal ini menyebabkan kerajinan sulam di Indonesia kalah pamor dengan kriya tekstil lainnya seperti batik dan songket. Padahal kerajinan sulam ini memiliki potensi yang sangat besar untuk dikembangkan. Saat ini mulai bermunculan berbagai UKM yang mengangkat kerajinan sulam tangan. Salah satunya yang berada di Jember Jawa Timur. Para pengrajin sulam di daerah ini memiliki kemampuan sulam yang mumpuni, namun sayangnya dari segi kemampuan desain mereka masih kurang. Para pelaku UKM ini kebanyakan belum mengangkat potensi daerah yang ada di sekitar mereka. Sehingga hasil kerajinan sulam mereka masih cenderung seragam dan tidak memiliki ciri khas yang menonjol satu sama lain. Melalui penelitian ini, diharapkan para pelaku UKM nantinya mampu mengembangkan hasil desain sulaman mereka dengan menggunakan pengembangan dari ragam hias yang terdapat di batik Jawa Timur. Sehingga mereka dapat mengembangkan produk mereka ke pangsa pasar yang lebih luas
\end{abstract}

Kata kunci: Ragam Hias, Sulam, Batik, Jawa Timur

\begin{abstract}
Hand embroidery is a one practice of craft that been rooting in Indonesia since a very long time ago. Commonly, hand embroidery applicated and found on various traditional item that use on various cultural ceremony, from traditional wedding, lid cover for gift, into up to detailing wardrobe. The practice of embroidery craft in Indonesia
\end{abstract}


widely growth in Sumatra and Borneo. Because of the high level of crafmenship and way too many time it takes to produce, Indonesian hand embroidery product become a rather expensive item. This thing causing many hand embroidery product in Indonesia lost its attraction to many Indonesian market compared to other Indonesian textile product such as Batik and Songket. Nowdays, there's handfull small bussines startup or locally named as UKM, that takes after sulam as their core and speciality's, one of the resides in Jember, a small city in east part of Java Island. Lots of local sulam artist in this area possessed a pretty good skill in sulam craft, however lack of design sense. These new UKM artist, still not digging around their local potential that surrounds them. Therefore, their product looks pretty much same and doesnt have any quirks that made them stands out in the crowded textile jungle. Through this research, we do hope that many local UKM artist will be able to grow their craft bussiness, especially embroidery in this matter of speaking, by using their local well known speciality pattern derived from tons of batik pattern in East Java.By doing that, hopefully they would be able to bring their product to a wider range of market segment.

Keywords: Ornament, Embroidery, East Java Batik

\section{PENDAHULUAN}

Indonesia merupakan negara yang kaya akan budaya. Berbagai macam kesenian dan ragam hias hadir di Indonesia. Kekayaan tekstil di Indonesia pun juga begitu beragam. Sebut saja yang paling populer seperti batik, songket, dan juga tenun. Kekayaan tekstil di Indonesia pun, tak bisa luput dengan kehadiran ornamen. Hampir di setiap tekstil tradisional di Indonesia selalu dihiasi oleh ornamanen-ornamen tertentu yang memiiki makna yang berbeda-beda. Setiap daerah di Indonesia memiliki bentukan ornamen yang berbeda-beda. Seperti misalnya ornamen di Kalimantan dan Sumatra banyak berbentuk geometris, sedangkan bentukan ornamen di pulau Jawa banyak berbentuk organis.

Jawa Timur memiliki $2 / 3$ wilayah yang terdiri dari pegunungan dan perbukitan. Masyarakat Jawa Timur memiliki 2 kecenderungan budaya, yang pertama adalah kelompok pendukung kebudayaan Jawa, dan yang kedua adalah kelompok pendukung kebudayaan Madura yang berada di pulau Madura dan pulau-pulau kecil di sekitarnya. Selain itu terdapat beberapa kelompok pedukung kebudayaan campuran Jawa dan Madura yang biasa disebut dengan budaya 
"Pandhalungan". Kelompok Pandhalungan ini banyak tersebar di beberapa daerah seperti Jember, Bondowoso, Situbondo dan Probolinggo.

Di Jawa Timur sendiri, hampir tiap kabupaten memiliki batik khas kabupaten tersebut. Motif dan ornamen yang ditampilkan dari batik khas kabupaten yang berada di Jawa Timur sangatlah beragam. Bentukan motif ini dipengaruhi oleh berbagai hal. Mulai dari flora dan fauna khas daerah tersebut, cerita rakyat, hasil bumi hingga dari corak turun temurun yang sudah ada sejak masa lampau. Seperti contohnya, batik mbako dari Jember yang menampilkan ornamen daun tembakau yang merupakan kekayaan daerah tersebut, atau batik Surabaya yang menampilkan ornamaen Suro dan Boyo yang merupakan cerita legenda asal usul nama Surabaya, atau Batik Banyuwangi dengan motif Gajah Oling yang merupakan motif tradisional sejak jaman kerajaan majapahit.

Sulam merupakan salah satu kerajinan yang sudah lama berada di Indonesia. Sulam mulai ada di Indonesia semenjak dibawa oleh para pedagang dari Eropa dan Cina yang banyak datang ke Indonesia pada masa penjajahan Belanda. Meskipun tak setenar songket ataupun tenun, namun tak bisa dipungkiri bahwa kerajinan sulam juga merupakan salah satu kekayaan budaya Indonesia.Kriya sulam yang ada di Indonesia tak hanya sekedar memiliki nilai estetis. Di beberapa daerah tertentu kriya sulam memilik fungsi sosial yang kental. Seperti di Aceh contohnya. Di Aceh sulam tidak digunakan dalam pakaian sehari - hari. Namun hanya digunakan sebagai perlengkapan pernikahan. Sulam Aceh banyak diaplikasikan pada hiasan pelaminan khas Aceh.

Namun sayangnya, seiring berjalannya waktu nilai-nilai sosial dan juga tradisi yang terkandung di kriya sulam sedikit demi sedikit mulai terkikis. Banyak yang menganggap bahwa kriya sulam hanyalah sebuah kerajinan tangan yang digunakan untuk menghiasi kain atau objek tertentu. Padahal dibalik itu semua, kriya sulam di Indonesia sangatlah kaya akan makna. Motif- motif yang ada, warna, benang dan juga material yang digunakan semuanya memiliki makna tersendiri. Masyarakat Indonesia juga masih banyak yang belum mengetahui bahwa sesungguhnya Indonesia memiliki kekayaan kriya sulam yang sangatlah kaya dan beragam. 


\section{KAJIAN TEORI}

\section{Teori Unsur Desain}

Desain memiliki pengertian yang luas intrepetasinya. Setiap bidang baik keilmuan maupun profesi dapat menggunakan kata desain di dalamnya. Secara umum proses desain dapat dipahami sebagai suatu proses penciptaan wujud dengan maksud tertentu. Desain ditujukan untuk menjawab permasalahan sosial.

Desain memiliki beberapa unsur penting. Unsur-unsur tersebut adalah a) Bentuk berupa Titik, Garis dan Bidang. Titik adalah unsur seni rupa yang paling dasar. Titik yang disambung terus menerus akan menciptakan sebuah garis. Kemudian dari gabungan garis ita akan mendapatkan sebuah bidang. Bentuk apa saja di alam ini dapat disederhanakan menjadi titik, garis, bidang dan gempal atau volume (Sanyoto, 2009). Dalam ilmu desain, setiap bentuk akan memiliki dan menempati ruang baik dwimatra ataupun trimatra; b) Tekstur adalah tampilan suatu benda yang dapat diraba dan dirasakan oleh sentuhan. Tekstur sering dikategorikan sebagai bagian dari corak suaru benda. Karena biasanya benda-benda yang memiliki tekstur tertentu akan menampilan sebuah corak yang berbeda satu sama lain; c) Peranan warna dalam desain sangatlah penting. Menurut Brewster setiap warna memiliki tiga macam ukuran yaitu Hue (corak), Value (nilai warna), dan Intensity (kekuatan warna); d) Bentuk positif dan negatif. Pada umumnya bentuk dipandang sebagai sesuatu yang menempati ruang, tetapi bentuk dapat pula dipandang sebagai ruang kosong yang dikelilingi ruang yang terisi (Wong, 1995). Bentuk yang dipandang sebagai pengisi ruang bisa disebut bentuk 'positif' sedangkan bentuk yang dipandang sebagai ruang kosong sebagai bentuk 'negatif'. Dalam penelitian thesis ini, terdapat peran positif-negatif. Teknik sulam secara umum menghasilkan bentukan positif-negatif pada kain yang dibentuk oleh benang sulam sebagai pengisi ruang

\section{Jenis Ragam Hias}

Menurut Drs. Aryo Sunaryo, M. Pd Seni, dalam Buku Ornamen Indonesia, ragam hias di Indonesia dibagi menjadi beberapa kelompok. Pembagian kelompok ini didasarkan pada bentukan dari ragam hias itu sendiri. Kelompok ragam hias itu adalah Ragam Hias Geometris dan Non Geometris. Ragam hias geometris terdiri 
dari ragam hias dengan bentuk Meander, Pilin, Lereng, Banji, Kawung, Jlamprang, dan Tumpal. Sedangkan ragam hias non geometris terdiri dari ragam hias manusia, ragam hias flora, ragam hias fauna, ragam hias benda alam dan lainnya.

\section{Jenis Ragam Hias Pada Batik Jawa Timur}

Fisiografi Jawa Timur memiliki wilayah $2 / 3$ terdiri dari pegunungan dan perbukitan. Dataran rendah terletak sepanjang daerah aliran sungai dan wilayah pantai. Ciri-ciri fisik propinsi Jawa Timur sebelah utara terdiri dari pegunungan kapur dan relatif tidak subur, sebelah selatan meliputi gugusan pegunungan kapur dan pegunungan kidul, dengan tingkat kesuburan yang rendah.

Saat ini propinsi Jawa Timur memiliki kurang lebih sekitar 76 jenis Batik dengan ragam hias yang berbeda dari kurang lebih 25 kabupaten yang ada di Jawa Timur. Salah satu ciri khas utama dari batik Jawa Timur adalah penggunaan warnawarna cerah seperti merah dan hijau sebagai latar batik. Selain itu, di Batik Jawa Timur kita dapat banyak menemukan bentuk ragam hias flora dan fauna. Biasa bentuk ragam hias flora dan fauna ini merupakan flora dan fauna yang menjadi ciri khas daerah tersebut. Misal kabupaten Jember dengan batik Mbako nya yang menampilkan ragam hias daun tembakau yang merupakan flora khas daerah tersebut. Kemudia ada pula Batik Coto'an dari Situbondo yang menampilkan ragam hias berbentuk kerang-kerangan yang juga merupakan kekayaan lokal kabupaten Situbondo.

\section{METODE PENELITIAN}

Dalam penelitian ini dilakukan beberapa tahapan penelitian yaitu: a) Teknik perolehan data. Data diperoleh melalui komunitas pencinta sulam di Indonesia dan juga para pengrajin sulam di Indonesia; b) Kajian Pustaka. Kajian pustaka didapatkan dari berbagai sumber seperti penelitian terdahulu, jurnal - jurnal ilmiah dan juga berbagai macam refrensi buku yang membahas baik tentang batik Jawa Timur, ragam hias, kerajinan sulam, maupun inovasi produk handmade; c.) Wawancara / interview/ Kuisioner. Wawancara akan dilakukan kepada pelaku bisnis sulam di Indonesia dan juga para pengrajin sulam. Wawancara ini ditujukan agar peneliti mendapatkan gambaran tentang sejauh mana perkembangan kriya 
sulam di Indonesia. Kemudian peneliti juga melakukan sebar kuisioner kepada responden yang dimana hal ini nantinya akan ditujukan kepada responden dengan rentang usia 17 - 30 yang tinggal di daerah perkotaan. Hal ini dilakukan agar peneliti mengerti bagaimana selera pasar yang ada saat ini; d) Metodologi penelitian. Metodologi penelitian dilakukan dengan menggunakan metodologi penelitian kualitatif.

\section{HASIL DAN PEMBAHASAN}

\section{Konsep dan Proses Perancangan}

\section{Unsur Visual Warna}

Warna-warna yang sering muncul pada Batik Jawa Timur dianggap dapat mewakili jati diri dari Batik Jawa Timur. Warna-warna yang terpilih ini nantinya akan digunakan dalam proses pengembangan batik Jawa Timur. Dalam prosesnya, tidak menutup kemungkinan untuk menggunakan turunan dari warna tersebut. Namun, turunan warna yang akan digunakan hanya berdasarkan dari value atau gelap terang warna tersebut. Misal, menggunakan warna merah muda sebagai turunan dari warna merah, biru muda sebagai turunan dari warna biru, dan sebagainya.

\begin{tabular}{|c|c|}
\hline Warna Asli & Warna Turunan \\
\hline Merah & \\
\hline Hijau & \\
\hline Biru & \\
\hline Coklat & \\
\hline Kuning Kecoklatam & \\
\hline Putih & \\
\hline
\end{tabular}

Tabel 1. Warna Turunan dari Warna Batik Jawa Timur

Sumber: Dokumentasi Penulis 


\section{Unsur Visual Bentuk}

Dari hasil analisis yang dilakukan didapatkan sebuah kesimpulan bahwa jenis ragam hias yang banyak muncul di batik Jawa Timur adalah ragam hias flora dan fauna. Untuk ragam hias flora yang paling banyak muncul adalah bentuk ragam hias flora dan fauna. Bentuk ragam hias flora yang banyak muncul adalah bentuk ragam hias bunga dan daun. Sedangkan untuk ragam hias fauna bentuk yang banyak muncul adalah bentuk ragam hias burung dan ayam bekisar.

Proses stilasi yang dilakukan terhadap ragam hias batik JawaTimur ini adalah menyederhanakan bentuk dari ragam hias yang terdapat di batik Jawa Timur. Penyederhanaan bentuk ini bertujuan untuk mempermudah proses produksi pada UKM dan juga meningkatkan kuantitas dari hasil produksi.

\section{Bentuk Ragam Hias Flora}

Dari bentuk ragam hias flora yang banyak muncul pada batik Jawa Timur yaitu bentuk bunga dan daun, peneliti akan menggunakan ciri khas bentukan kelopak bunga yang bertumpuk. Kemudian untuk bentuk daun, peneliti akan menggunakan bentuk daun dengan batang daun yang menyirip

\begin{tabular}{|c|c|c|c|}
\hline & Bentuk 1 & Bentuk 2 \\
\hline \multirow{2}{*}{ 㵄 } & 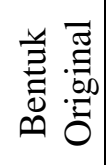 & & \\
\hline & 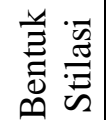 & & \\
\hline$\Xi$ & 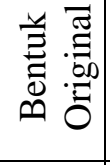 & & \\
\hline 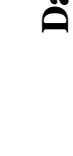 & 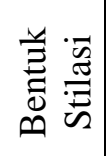 & & \\
\hline
\end{tabular}

Tabel 2. Hasil Stilasi Rgam Hias Flora pada batik Jawa Timur

Sumber: Dokumentasi Penulis 


\section{Bentuk Ragam Hias Fauna}

Bentuk ragam hias fauna yang akan digunakan sebagai ide pengembangan adalah burung dan ayam bekisar. Karena menurut hasil analisa kedua bentuk ragam hias inilah yang paling banyak muncul pada Batik Jawa Timur.

Bagian dari bentuk burung yang akan digunakan adalah gerakan kepakan sayap burung yang banyak ditampakkan pada Batik Jawa Timur. Kemudian untuk ragam hias ayam bekisar, peneliti akan mengambil ciri khas jengger yang berada di dekat paruh ayam. Selain itu, bagian ekor ayam bekisar yang menonjol dan tinggi juga menarik untuk dijadikan inspirasi proses stilasi nantinya.

Karena bentuk ragam hias buarung yang terdapat pada batik Jawa Timur umumnya bersifat detail dan kompleks, makan peneliti akan menyederhanakan bentuk kompleks tersebut menjadi lebih sederhana. Hal ini dilakukan agar memudahkan dalam proses penyulaman nantinya.

\begin{tabular}{|l|c|c|}
\hline & Burung & Ayam Bekisar \\
\cline { 2 - 4 } & & \\
\hline \multirow{2}{*}{0} &
\end{tabular}

Tabel 3. Hasil Stilasi Ragam Hias Fauna pada batik Jawa Timur Sumber: Dokumentasi Penulis 


\section{Desain Final}

\section{Ragam Hias 1}

Ragam Hias 1 terisnspirasi berdasarkan bentuk dari ragam hias batik Tase Melaya yang berasal dari Tanjung Bumi. Ragam hias ini menampilkan bentuk bunga yang bertumpuk-tumpuk. Kemudian, melalui proses stilasi peneliti menyederhanakan bentuk bunga yang bertumpuk tersebut ke dalam bentuk yang lebih simpel. Bentuk ragam hias bary yang dibuat, merupakan bungan dengan kelopak berjumlah delapan buah. Di bagian dalam bunga juga terdapat bentuk kelopak yang lebih kecil lagi yang juga berisi 8 buah kelopak bunga. Untuk teknik sulam yang digunakan, ragam hias 1 menggunakan teknik satin stitch di bagian kelopak dalam bunga, dan chain stitch untuk kelopak bagian luar

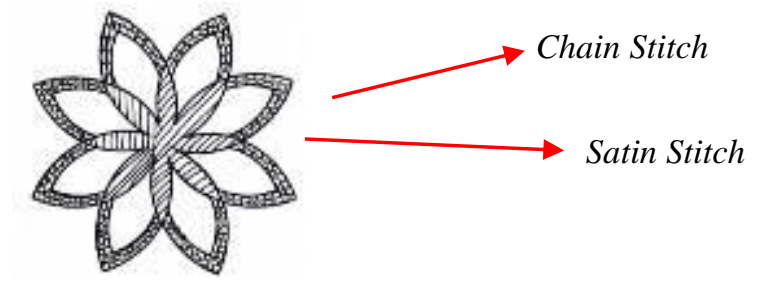

\section{Gambar 1. Jenis Teknik Sulam yang digunakan}

Sumber: Dokumentasi Pribadi

Ragam hias 1 dapat divariasikan dari segi warna. Selain itu, dalam pengaplikasiannya nanti ragam hias 1 ini dapat dimodifikasi penyusunan pola ragam hias sesuai dengan kreativitas pengrajin.

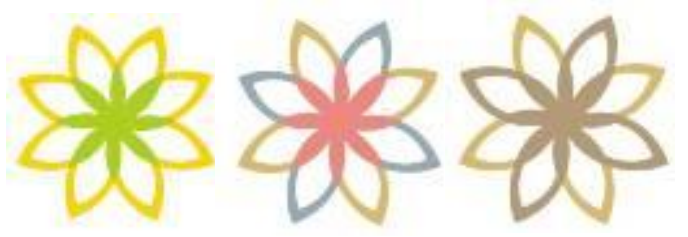

Gambar 2. Contoh Variasi Warna

Sumber: Dokumentasi Pribadi 

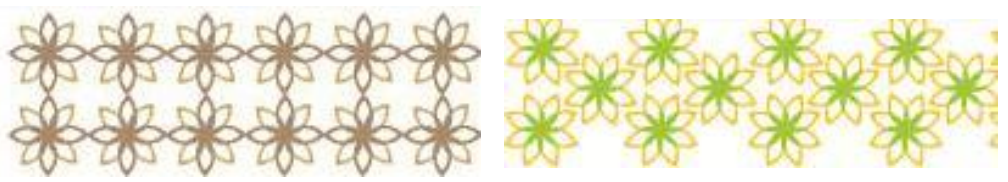

\section{Gambar 3. Contoh Variasi Pola Penyusunan}

Sumber: Dokumentasi Pribadi

\section{Ragam Hias 2}

Ragam hias 2 mengambil bentuk ragam hias bunga dari batik Ceplok Bunga Sidoarjo. Ragam hias ini menampilkan bentuk bunga dengan kelopak bersusun. Warna Kelopak bagian dalam dan luar berbeda. Kemudian susunan kelopaknya berbentuk setengah lingkaran atau kuncup. Melalui proses stilasi, peneliti menyederhanakan bentuk bunga tersebut kedalam bentuk yang lebih simpel. Peneliti mengambil ciri khas kelopak yang bertumpuk tersebut dan bentuk kelopak bunga yang tidak mekar sempurna. Bentuk ini hampir mirip dengan ragam hias 1, hanya saja jumlah kelopak bunga dan bentuk susunan kelopak yang membedakan bentuk ragam hias 2 dengan ragam hias 1 . Sama seperti ragam hias 1, ragam hias 2 menggunakan teknik sulam satin stitch untuk kelopak bagian dalam, kemudian untuk kelopak bagian luar menggunakan teknik chain stitch.

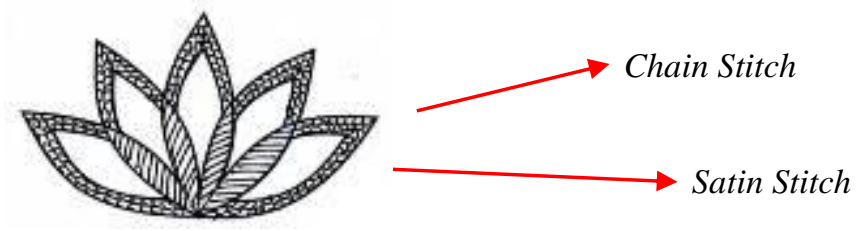

\section{Gambar 4. Jenis teknik Sulam yang digunakan}

Sumber: Dokumentasi Pribadi

Ragam hias 2 dapat divariasikan dari segi warna. Selain itu, dalam pengaplikasiannya nanti ragam hias 2 ini dapat dimodifikasi penyusunan pola ragam hias sesuai dengan kreativitas pengrajin. 

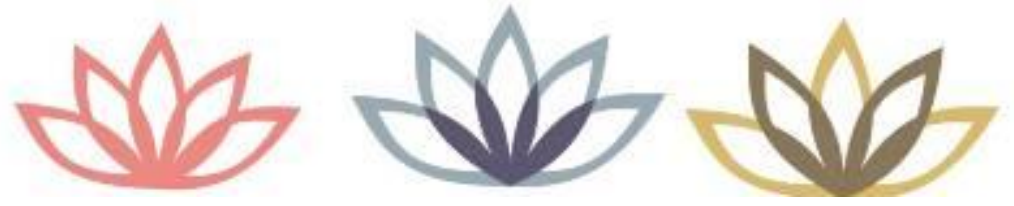

\section{Gambar 5. Contoh Variasi Warna}

Sumber: Dokumentasi Pribadi
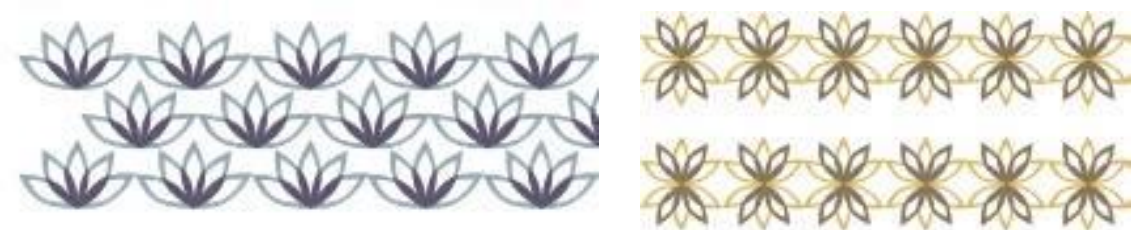

\section{Gambar 6. Contoh Variasi Pola Penyusunan}

Sumber: Dokumentasi Pribadi

\section{Ragam Hias 3}

Ragam hias 3 mengambil bentuk ragam hias daun dari Batik Mbako Jember. Bentuk ragam hias daun pada batik mbako jember menampilkan bentuk daun tembakau dengan tulang daun yang bercabang. Melalui proses stilasi peneliti menyederhanakan bentuk daun tersebut menjadi bentu yang lebih sederhana. Ragam hias 3 menampilkan bentuk daun dengan tulang daun yang sejajar namun susunannya asimetris, tidak sama kanan dan kirinya.

Untuk teknik sulam yang digunakan, ragam hias 3 menggunakan teknik sulam chain stitch pada bagian outline daun dan tulang daun bagian tengah, kemudian unk bagian tulang daun di bagian dalam kanan dan kiri menggunakan teknik running stitch

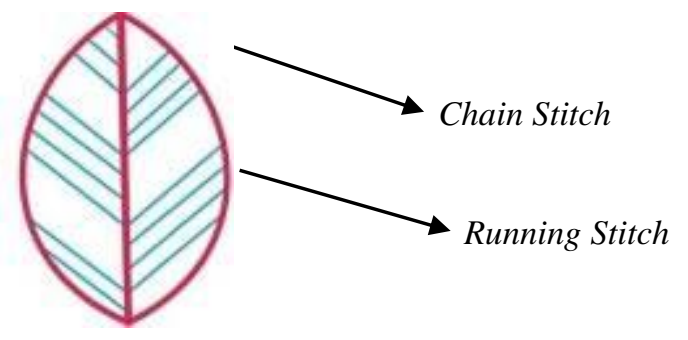

Gambar 7. Jenis teknik Sulam yang digunakan

Sumber: Dokumentasi Pribadi 
Ragam hias 3 dapat divariasikan dari segi warna. Selain itu, dalam pengaplikasiannya nanti ragam hias 3 ini dapat dimodifikasi penyusunan pola ragam hias sesuai dengan kreativitas pengrajin.
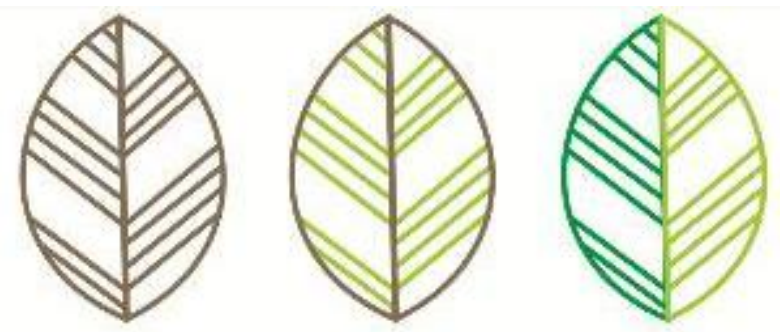

Gambar 8. Contoh Variasi Warna

Sumber: Dokumentasi Pribadi
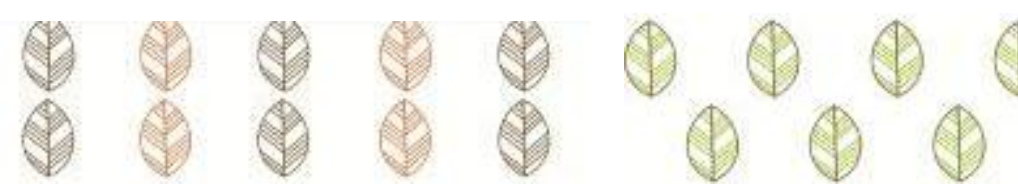

\section{Gambar 9. Contoh Variasi Pola Penyusunan}

Sumber: Dokumentasi Pribadi

\section{Ragam Hias 4}

Ragam Hias 4 mengambil bentuk ragam hias yang terdapat pada batik Sata Ganda wangi dari Bojonegoro. Bentuk ragam hias pada batik Sata Ganda Wangi ini menampilkan tumbuhan tembakau dengan bentuk daun yang lurus sejajar. Melalui proses stilasi, peneliti mengubah bentuk daun tersebut menjadi bentuk yang lebih sederhana. Ragam Hias 4 menampilkan bentuk daun yang bersusun ke atas, dengan ukuran semakin ke atas semakin mengecil. Untuk teknik sulam yang digunakan, ragam hias 4 menggunakan teknik sulam satin stitch pada seluruh bagian ragam hias.

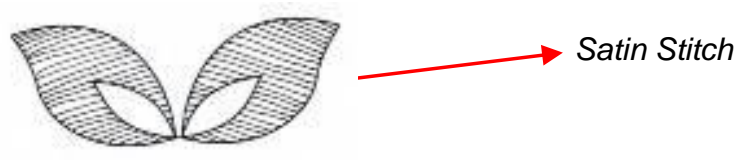

Gambar 10. Jenis teknik Sulam yang digunakan

Sumber: Dokumentasi Pribadi 
Ragam hias 4 dapat divariasikan dari segi warna. Selain itu, dalam pengaplikasiannya nanti ragam hias 4 ini dapat dimodifikasi penyusunan pola ragam hias sesuai dengan kreativitas pengrajin.

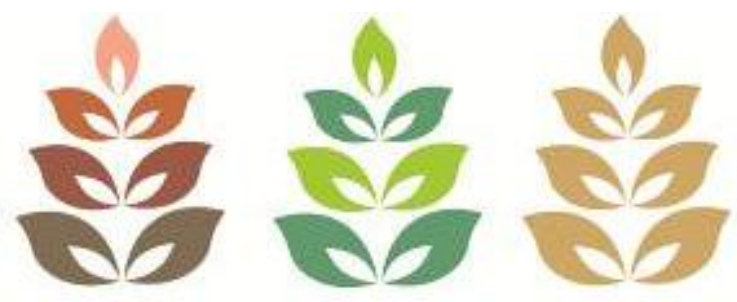

Gambar 11. Contoh Variasi Warna

Sumber: Dokumentasi Pribadi

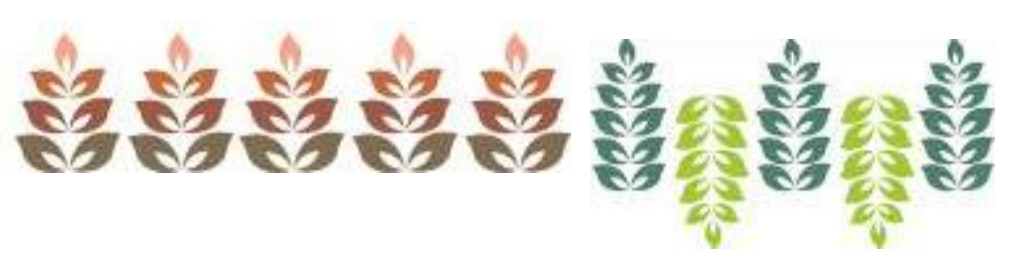

Gambar 12. Contoh Variasi Pola Penyusunan

Sumber: Dokumentasi Pribadi

\section{Ragam Hias 5}

Ragam hias 5 mengambil bentuk dari ragam hias yang terdapat pada batik Alas Obong dari Tulungagung. Bentuk ragam hias yang diambil adalah bentuk ragam hias burung yang sedang mengepakkan sayapnya. Melalui proses stilasi, peneliti menyederhanakan bentu burung tesebut menjadi bentuk yang lebih sederhana. Ragam hias 5 menampilkan bentuk siluet burung yang sedang mengepakkan sayapnya ke atas. Untuk teknik sulam yang digunakan, ragam hias 4 menggunakan teknik sulam satin stitch pada seluruh bagian ragam hias.

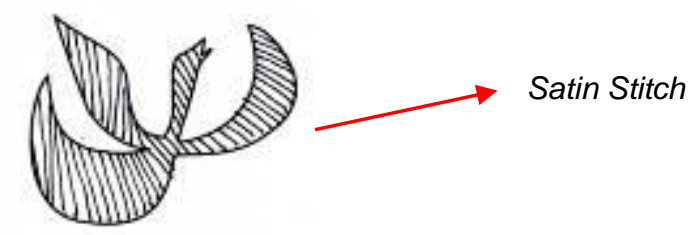

\section{Gambar 13. Jenis teknik Sulam yang digunakan}

Sumber: Dokumentasi Pribadi 
Ragam hias 5 dapat divariasikan dari segi warna. Namun, karena ragam hias ini hanya terdiri dari satu bagian saja jadi hanya bisa menggunakan satu warna untuk satu bentuk ragam hias. Selain itu, dalam pengaplikasiannya nanti ragam hias 5 ini dapat dimodifikasi penyusunan pola ragam hias sesuai dengan kreativitas pengrajin.
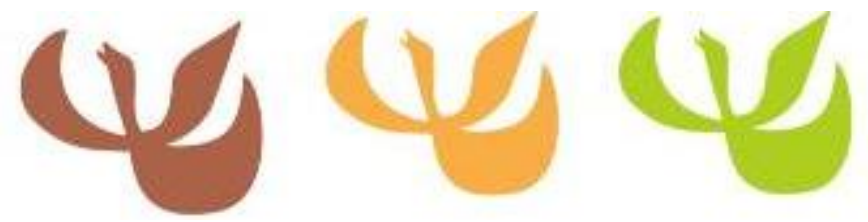

Gambar 14. Contoh Variasi Warna

Sumber: Dokumentasi Pribadi

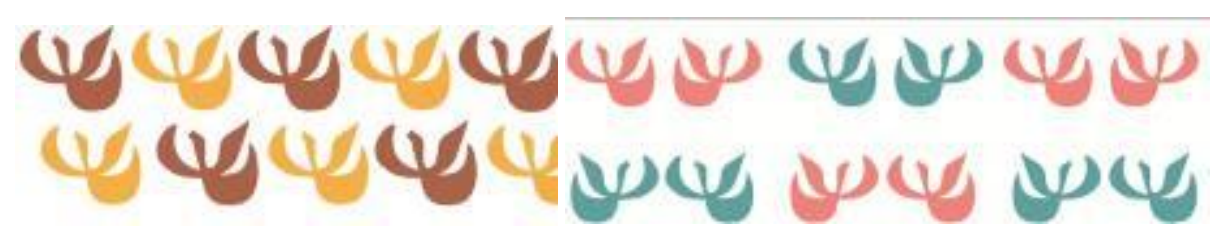

Gambar 15. Contoh Variasi Pola Penyusunan

Sumber: Dokumentasi Pribadi

\section{Ragam Hias 6}

Ragam hias 6 mengambil bentuk dari ragam hias ayam bekisar yang terdapat pada Batik Probolinggo. Ragam hias ayam bekisar yang terdapat pada batik Probolinggo ini menampilkan bentuk ayam bekisar yang sedang berdiri dengan tegak. Melalui proses stilasi peneliti menyederhanakan bentuk dari ayam bekisar tadi menjadi bentuk ragam hias yang lebih simpel. Bentuk ragam hias 6 ini menampilkan bentuk ayam bekisar yang menonjolkan ciri khas nya yaitu terdapat jengger dan janggut dan juga bagian ekor yang tinggi. Untuk teknik sulam yang digunakan, ragam hias 6 menggunakan teknik sulam chain stitch pada bagian outline kemudian untuk bagian dalam teknik running stitch. 


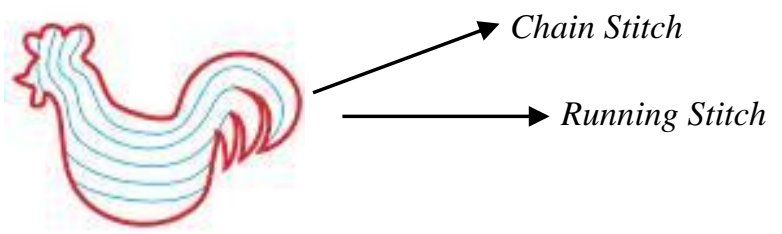

\section{Gambar 16. Jenis teknik Sulam yang digunakan}

Sumber: Dokumentasi Pribadi

Ragam hias 6 dapat divariasikan dari segi warna. Selain itu, dalam pengaplikasiannya nanti ragam hias 6 ini dapat dimodifikasi penyusunan pola ragam hias sesuai dengan kreativitas pengrajin.
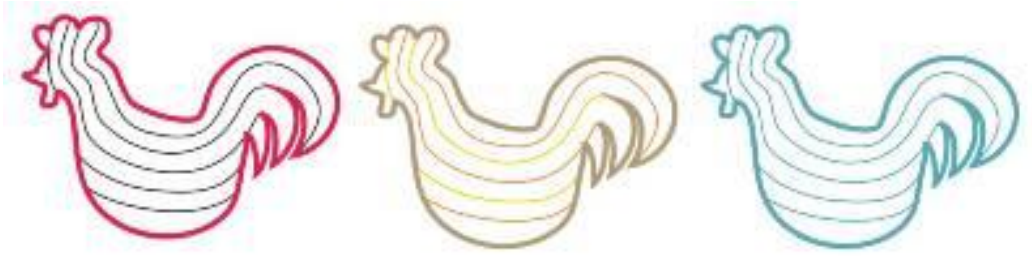

Gambar 17. Contoh Variasi Warna

Sumber: Dokumentasi Pribadi
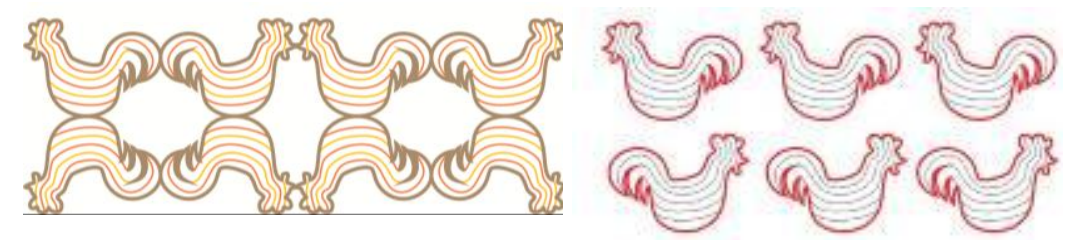

Gambar 18. Contoh Variasi Pola Penyusunan

Sumber: Dokumentasi Pribadi

\section{SIMPULAN DAN SARAN}

\section{Simpulan}

Berdasarkan hasil penelitian yang telah dilakukan, maka dapat disimpulkan hasil dari penelitian sebagai berikut: a) Warna Dominan pada Batik Jawa Timur. Warna-warna yang banyak muncul pada batik Jawa Timur merupakan warnawarna solid yang cerah merah, hijau, dan biru. Selain itu banyak muncul juga warna coklat dan hitam. Batik berwarna cerah banyak ditemukan di daerah Jawa 
Timur sebelah Timur seperti Lumajang, Jember, Bondowoso dan sekitarnya; b) Bentuk Ragam Hias yang Banyak Muncul pada Batik Jawa Timur. Dari hasil analisa yang telah dilakukan, bentukan ragam hias yang banyak muncul pada batik Jawa Timur adalah bentuk ragam hias flora dan fauna. Bentuk flora dan fauna ini biasanya dipengaruhi oleh kekayaan alam yang berada di sekitar daerah tersebut. Flora: Dari bentuk ragam hias flora, banyak ditemukan ragam hias berbentuk bunga dan daun. Untuk ragam hias berbentuk bunga terdapat ciri khas bentuk yaitu kelopak bunga yang dibuat dengan saling bertumpuk. Kemudian untuk bentuk daun terdapat ciri khas bentuk daun dengan tulang daun berbentuk menyirip. Selain daun dan bunga, banyak pula ditemukan ragam hias dengan bentuk tanaman lain seperti padi dan bambu, dan juga ragam hias berbentuk buah-buahan seperti anggur dan mangga. Fauna: Untuk ragam hias berbentuk fauna, banyak ditemukan bentuk ragam hias burung dan ayam bekisar. Ragam hias burung pada batik Jawa Timur memiliki ciri khas yaitu posisi burung selalu dalam keadaan mengepakkan sayap, bentuk sayap yang bertumpuk dan ekor belakang yang panjang dan meliuk. Untuk bentuk ragam hias ayam bekisar yang merupakan hewan khas Jawa Timur, bentuk ayam bekisar ini memiliki ciri khas bentuk ekor belakang yang menukik ke atas, serta terdapat jengger pada bagian kepalanya. Selain burung dan ayam, dapat pula ditemukan bentuk hewan yang lain seperti ikan dan kerang-kerangan; c) Dalam proses stilasi atau penyederhanaan ragam hias yang terdapat pada batik Jawa Timur, penulis melakukan proses stilasi berdasarkan jenis ragam hias yang benyak muncul dari Batik Jawa Timur. Yaitu ragam hias berbentuk bunga, ragam hias berbentuk dau, ragam hias berbentuk durung dan ragam hias berbentuk ayam. Dari proses stilasi ini didapatkan 6 buah bentuk ragam hias baru yang terdiri dari 2 bentuk ragam hias bunga, 2 bentuk ragam hias daun, 1 bentuk ragam hias burung dan 1 bentuk ragam hias ayam; d) Untuk proses pengaplikasian desain akhir, penulis menggunakan jenis teknik sulam dasar yaitu Running Stitch, Chain Stitch dan Back Stitch. Pemilihan jenis tekni sulam dasar ini berdasarkan alasan untukmempermudah proses sulam bagi pengrajin, membuat kerja pengrajin semakin efisien sehingga meningkatkan kuantitas dari hasil produksi. Untuk pengaplikasian pada produk, penulis membebaskan pengrajin dalam berkreasi. 
Pengrajin dapat mengaplikasikan hasil dari desain akhir di mana saja sesuai dengan kebutuhan mereka.

\section{Saran}

Selama penelitian berlangsung, terdapat beberapa kekurangan baik dalam pelaksanaan maupun proses analisis dara. Saran yang dikemukakan berikut ini diharapkan dapat memberikan perbaikan bagi penelitian selanjutnya.

Ragam hias merupakan salah satu kekayaan budaya di Indonesia. Keberagaman ragam hias di Indonesia masih sangat luas untuk digali. Penelitian ini hanya difokuskan pada Ragam hias yang terdapat pada batik Jawa Timur. Pada penelitian selanjutnya dapat dikembangkan lagi dengan memperluas cakupan kasus penelitian. Sehingga diharapkan hasil penelitian berikutnya dapat dimanfaatkan sebagai referensi dalam mengeksplorasi ragam hias yang terdapat di Indonesia.

Pengaplikasian hasil dari desain akhir penelitian ini baru dilakukan pada kerajinan sulam tangan. Pada penelitian selanjutnya, pengaplikasian hasil eksplorasi desain ragam hias batik Jawa Timur dapat diaplikasikan pada jenis kerajinan yang lain.

Penelitian ini baru menghasilkan desain akhir saja. Belum mengidentifikasi tanggapan pasar terhadap hasil dari pengembangan Ragam hias. Pada penelitian selanjutnya, dapat dilakukan studi pasar untuk mengetahui tanggapan pasar terhadap hasil eksplorasi.

\section{DAFTAR PUSTAKA}

Sanyoto, Sadjiman Ebdi. 2009. Nirmana: Elemen-elemen Seni dan Desain. Yogyakarta: Jala Sutra.

Sunaryo, Aryo. 2009. Ornamen Nusantara Kajian Khusus tentang Ornamen Indonesia. Semarang: Dahara Press

Wong, Wucius. 1986.. Beberapa Asas Merancang Dwimatra. Bandung: Penerbit ITB. 